\title{
Editorial on the special issue "Geographies of Demographic Change: Theories and Narratives"
}

\author{
Birgit Leick, Birgit Glorius
}

\section{Introduction to the special issue}

Demographic challenges and their various effects on European countries and regions have long been debated among policymakers, practitioners and scholars (see, for example, Bloom/Canning 2008; Börsch-Supan 2008, 2013; Steinführer) Haase 2007; Ferry/Vironen 2011; Kröhnert et al. 2011; Swiaczny 2010). Despite a broad body of mainly empirical literature which exists both in research and practice of the social sciences and population studies, far less attention has been paid to the conceptual approaches underlying these debates. Notably, our observations show that the conceptual underpinnings and narrative elements associated with common terms such as "demographic change" or "demographic decline" are typically not touched upon in mainstream debates. Consequently, this special issue of "Comparative Population Studies" is motivated by the idea of framing a broader understanding of these phenomena by critically reflecting the all too often taken-for-granted views, theories and concepts that are used for studying demographic change, as well as their implications from a multi-scalar, multi-actor and multidisciplinary perspective. Taking the normative dimension of discourses on demographic change into account, this issue particularly intends to move beyond positivist theorising or practical perspectives by focusing on the socio-temporal and socio-spatial contexts of demographic processes and challenges, i.e., the "geographies of demographic change". By "geographies of demographic change", we mean different and contextspecific configurations of regional demographic change. In this issue, they will be approached from a European perspective. Such contexts include, for example, urban versus rural areas, or federally organised states in Germany versus centrally organised countries in Northern Europe. The scope of the present special issue also addresses social change that accompanies demographic processes, including marginalisation and peripheralisation as two conceptual approaches.

The contributions gathered in this special issue, including this editorial, thus intend to stimulate an interdisciplinary discourse on demographic change, focusing on different socio-temporal and socio-spatial contexts for demographic change. Altogether, these papers highlight the need to pay specific attention to the disciplinary origins and variety of the main terms used to denote demographic change and its 
effect. They also stress the sometimes conflictual and normative character of the connotations connected to the different debates. To do so, the dominating scholarly approaches and the prevailing paradigms underlying these approaches are critically examined by discussing their openness towards, and reflections of, the variety and idiosyncrasies of different socio-spatial and socio-economic configurations. It is our aim to enhance the existing scholarly knowledge on the narratives, discourses and conceptualisations of demographic change and related phenomena, and elaborate how public debates are both intertwined with, and reflected in, specific policies and governance mechanisms. This will be achieved by bringing together academic expertise from different disciplines and fields such as economic geography, social and cultural geography, sociology, and political science.

Looking at one of the most controversially discussed topics of the past years, the European migration crisis (which unfolded at the time the field work for the articles in this special issue was carried out), the need for putting greater effort into contextualising demographic processes becomes strikingly visible. In the public debate, one can detect the transformative power of the demographic discourses associated with this crisis. Some of the urgent questions arising in the context of these immigration flows, for example housing and education, labour market participation, etc. within Germany, are completely separated from other discourses, which are linked to migration or demographic challenges as well. For instance, the issue of sustainable development perspectives for peripheralised regions, the quantitative and qualitative development of the labour force for ageing populations, or the effects of European integration and migration policies on the mobility of qualified migrants in Europe are some of the questions that are being left unexamined. Instead, the main discourse on the recent migration challenges in the EU focuses on the humanitarian aspects, which is easily understandable given the shock-like, sudden influx of over one million people into countries such as Germany. Demographic processes such as contemporary external migration movements also challenge the ongoing discourses about demographic change. In the light of recent migration, issues of social and cultural change, the general adaptability of the social system towards a fastchanging composition of society and context-sensitivity clearly gain importance.

This editorial first maps the main debates on demographic challenges from a European perspective, and then critically analyses the mainstream paradigms underlying these contemporary debates. This is followed by a brief survey of conceptual approaches that might be helpful when it comes to conceptualising demographic change (for instance: agency, context, self-reflexivity and normative power). It is argued that such alternative views on demographic processes are fruitful to amend the existing explanations and to better understand how demographic change shapes specific socio-spatial and socio-temporal settings. The editorial finally introduces the articles included in this special issue which discuss these alternative conceptual elements such as peripheralisation (Leibert/Golinski 2017), globalisation peripheries (Matuschewski et al. 2017), and resource peripheries (Carson et al. 2016). The articles also propose discursive or narrative approaches in order to improve our understanding of demographic change, either as narratives and representations in speech that produce and reproduce problems and stigmata associated with 
demographic change (Meyer et al. 2016; Bart//Sackmann 2016), or as discourses which instead reflect the entrepreneurial opportunities linked to demographic challenges (Christmann 2017). Most contributions contain empirical cases that focus on rural-peripheral Eastern Germany, where population ageing and decline, coupled with youth emigration, have long since weakened socio-economic development perspectives. Analysing the dynamics of population decline, peripheralisation processes and concomitant discourses in Eastern Germany may lead to an enhanced understanding and may function as representative example for demographic developments to come - also in other parts of Europe. The respective case studies are thus relevant for a reassessment of demographic discourses in a European perspective. Another case is Sweden's North, where low population density complicates local development in the Nordic periphery (Carson et al. 2016).

\section{The geographies of demographic change: what is achieved?}

\subsection{Mapping the debates}

The demographic development of European societies has long been debated among policymakers, practitioners and scholars alike. Population decline, population ageing, youth migration and, to a lesser extent, the movement of elderly people are all central themes that have been addressed from different perspectives. This has resulted in a body of literature that seeks to formulate solutions to urgent practical problems which are associated with these demographic challenges. From a regional development perspective, both the conceptual approaches and the practice of policymaking have been oscillating around the pivotal question of how the competitiveness of regions, industries and companies, and the provision of basic services (education, health service, public transport, and retail trade) can be sustained in socio-spatial contexts that are burdened by persistent outmigration, rapid population ageing and quantitative population decline as the three inter-related dimensions of the contemporary demographic challenges. All of these processes interactively result in various complex, and partly unpredictable, challenges at different spatial scales, involving private industries and companies, state-governed organisations and civil society. The changing population size and structure might even endanger the long-term economic viability of some types of regions, such as remote rural regions and peripheral places where infrastructures will never keep pace with urbanised agglomerations that tend to benefit from migration. In addition, such demographic processes will ultimately modify the conditions for local policymaking and planning because policies that might have been adequate for periods of population (and economic) growth must be renewed in response to changing settings in terms of population decline and ageing.

Despite a broad strand of mainly empirical and applied research, several questions with respect to these observations are, to date, still largely under-explored. First, although various theories and concepts implicitly address demography and population change, the explanatory power of demographic change as a conceptual 
perspective for describing and understanding the recent transformation of societies, economies and regions is still an unresolved issue. Second, many of the approaches that explicitly model demographic key indicators (for instance, economic models) do not specifically reflect upon the way in which demographic challenges are narrated and dealt with, or how such a conceptual engagement can contribute to a broader perspective on demographic change. Exceptions include van de Kaa (1996) who summarises the state-of-the-art knowledge on fertility in population studies from a narrative perspective. Against the backdrop of the multi-layered challenges and opportunities attached to phenomena such as population ageing, population shrinking, migration, etc., our knowledge is limited with respect to how and to what extent academic debates that challenge mainstream paradigms of (economic) growth and go beyond practical problem-analysis or problem-solving can enrich the contemporary debate across various disciplines.

\subsection{Similar concepts, different foci}

The study of demographic processes and challenges from a European perspective is marked by a co-existence of various disciplinary approaches in the wider field of the social sciences (such as economics, business administration, human and applied geography, political science, demography studies, and sociology) and beyond (population statistics, policy development), which all address similar phenomena, but have different foci. Depending on the disciplinary origins, there is no all-embracing definition upon which the geographies of demographic change might be based. Moreover, the terminology used to denote demographic processes is, to a large extent, rooted in both past and ongoing public discussions, policy and academic debates, and media articles, which, in turn, have moulded not only the debate but also the terms used. This interaction, in turn, has resulted in a bundle of partly overlapping or contradictory terms and definitions used to refer to demographic challenges, but without making the origins of the terms and/or related debates explicit. It is therefore worthwhile to describe the core of some of the most prominent terms in order to reveal their specific meanings and connotations, but also their "blind spots", which are left open, particularly from a cross-disciplinary perspective.

"Demographic change" is the most prominent term, which is often used to describe different and related changes in fertility and mortality or lifestyles, and the resulting phenomena such as population ageing and decline. Migration is another factor that affects these key indicators, not only in quantitative terms but also with regard to the structure and heterogeneity of a population. The field of policy development in particular uses the term "demographic change" to describe processes of population shrinking and ageing. This, however, only reflects a partial understanding of the demographic developments and challenges in the past and nowadays, neglecting growing intra-societal differentiation and heterogeneity due to inward or outward migration patterns or singularisation.

"Demographic decline" or alternatively "population decline" mainly refer to the long-term trend of a decreasing population, which is caused by changing mortality, fertility, or migration patterns, and their interaction. These terms are frequently 
used both in scientific and public debates on demographic processes. Referring to "decline" clearly adds a normative component to what is understood by them, as it is associated with the negative character of these processes.

By contrast, the term "demographic transition" describes the causes and effects of the transformation of societies, originating from dropping fertility and mortality rates, a process that is associated with changing regimes of production and consumption throughout history. These processes accompanied the so-called "first demographic transition" from an agrarian to an industrialised society (Coale 1975; Thompson 1929). The "second demographic transition" occured when modern societies changed to post-modern societies (see Lesthaeghe 1995; van de Kaa 1994, 2001), with this transition process being of primary importance for the phenomena addressed in this special issue.

The fourth term, "population change", captures the statistical side of these three main definitions used in most debates in the social sciences and beyond. "Population change" in a statistical sense is the mere description and interpretation of fertility, mortality, and migration indicators. The term is neutral as it describes population development in general, but its usage in the public debate often overlaps with the term "demographic change", which makes it difficult to separate the two related notions clearly, particularly from an applied perspective on demographic phenomena and challenges.

Consequently, debating such demographic challenges based upon various and partly overlapping or even conflicting definitions, terms and meanings risks producing and reproducing isolated knowledge that lacks inter-connectedness. Thus, it becomes difficult to identify the connections between the different research approaches and traditions and the sources of synergies for establishing multidisciplinary conceptions of similar topics. The parallel, yet unconnected use of these notions and terms hinders some of the necessary clarity about the core phenomena that are dealt with, which certainly limits the potential of cross-fertilisation between scholarship, public policy management and planning practice and thus prevents knowledge expansion through a change in perspective.

The boundaries between the thematic cores of the most important disciplines and research traditions in the social sciences and population studies, which deal with demographic processes and challenges from a European perspective, are equally blurred.

In economics, the academic debate predominantly focuses on theories of economic growth and specific economic sectors in which demography influences economic outcomes (or vice versa), for instance, educational and health systems, or the age-retirement provisions of economies (Börsch-Supan et al. 2015; Kuhn et al. 2014). The economic debate has converged around two different topics: population growth in terms of over-population and its economic consequences in developing nations in a Malthusian tradition (Birdsall et al. 2001; Bloom et al. 2003) versus population decline or ageing and migration, and how it affects the competitiveness of industrialised economies (Kelley/Schmidt 2005; Oliveira Martins et al. 2005; Poot 2008). While the first issue received more attention in the past, the latter stream of research has gained popularity in recent years (Bloom et al. 2010). From an eco- 
nomic perspective, demographic change is modelled as an exogenous factor that affects the demand of private households and labour markets (Franz 2004; Lührmann 2005) and implies changes in private markets as well as in the provision of public goods and services (general welfare, health and education), as highlighted by Börsch-Supan et al. (2015), Kuhn et al. (2014), Bengtsson/Scott (2011), Meier/Werding (2010) or Misoulis (2008). Other contributions discuss its long-term impact on human capital and skills (Poot 2008; see, also, Green 2003; Brown/Danson 2003). Some of the literature specifically investigates how population decline and ageing influence entrepreneurial activities and innovation (Bönte et al. 2007; Harhoff 2008).

By contrast, business researchers have approached demographic change from a "hands on" perspective to address different issues with practical relevance for business leaders and researchers (see, for instance, Pompe 2012; Reidl 2007). The purchasing power of elderly consumers and the market opportunities for business organisations with the so-called "silver agers" (Kohlbacher et al. 2014; Kohlbacher) Herstatt 2008; Kunisch et al. 2011; Suprinovic/Kay 2009), the new requirements of human resources policies within business organisations and public administration (Streb et al. 2008; Thun et al. 2007; Verworn et al. 2009), and the management and leadership topics for ageing societies (Tulik 2014; Kuebler et al. 2009) are some of the relevant debates.

In the field of regional science and human geography, studying the effects of demographic change on specific segments of local economies (retail trade and real estate markets) or on the provision of public goods and services (Maretzke 2014; Leick 2013; Matuschewski/Leick 2012; Neu 2009; Sackmann et al. 2008) are the most important issues addressed. With respect to context, this research explores demographic change for rural regions (BMVBS/BBSR 2009), urban settlements (Martinez-Fernandez et al. 2012; Nuissl/Rink 2005) or regions affected by economicpolitical transformation (Kurek 2011; Steinführer/Haase 2007). This strand of mostly empirical literature, however, lacks a critical reflection of the underlying conceptual understanding of demographic change (exceptions include Steinführer et al. [2014] and Leibert/Golinski [2017] in this special issue). Local development is thus reduced or "essentialised" in terms of demography without sufficiently incorporating the complexity of demographic processes, and research results are translated into policy recommendations, implicitly hypothesising that demographic processes are irreversible (see, for example, ARL 2016; Gans et al. 2006).

This approach to policymaking and regional planning, however, has become more contested recently, owing to its essentialist view on regional or social problems, which are all too often perceived as a result of demographic change. Barlösius/Neu (2007) criticise this as the "demographisation of society" (see, also, Leibert) Golinski 2017 in this issue). As a matter of fact, interpreting cultural, economic or social phenomena as the sole outcome of demographic processes such as population ageing and decline hides the fact that regional development paths and local options for taking action are, to a large extent, place-specific, individual, and path-dependent, and should thus be seen in context. Regional development studies that take on a historical perspective and discuss the spatial and temporal contingencies of localregional processes are rare, yet stress the need for contextualised understandings 
of the external factors influencing local development (see, for example, Hassink 2005 who contextualises historical industrial cycles and changing local economies).

Demography studies and sociology focus on demographic key indicators such as fertility and mortality trends to describe and contextualise the inter-relationship of social change and population developments (Barbi et al. 2008; Baudisch 2008; K/üsener/Goldstein 2016). This research tradition actively contributes to the building of a theory in line with general modernisation or social-demographic transition theories by considering and explaining the changing fertility behaviour of societies (Kirk 1996; Sobotka et al. 2011). However, heterogenisation or diversity as another important facet of demographic change is rarely addressed and, if so, often reduced to the issue of individualisation and how it affects fertility (Ehrhardt/Kohli 2011). Migration and its effects on societal development are typically handled within an isolated framework of migration and integration. For example, fertility patterns of immigrant women (Andersson 2004) or immigrant ageing and the provision of social care (Cangiano 2014) are studied without being connected to the broader context of demographic change. Vice versa, the existing literature on demographic change quite often lacks sensitivity towards place, space and time as important contextual factors for understanding the processes of demographic change.

In the political sciences, demographic change is addressed in a twofold way. Political economists approach the economic consequences of population changes from a systemic perspective, for example by discussing and analysing their influence on housing markets (Malmberg 2012). The recently emerging field of political demography addresses political change as a consequence of population dynamics (Goldstone et al. 2012; Sánchez-Gassen 2013). What both research strands have in common is that they focus on the political effects of demographic change using demographic data and concepts in an essentialist manner. In a similar vein, the practical side of policy advice concerning demographic change and related phenomena within societies (such as decline and ageing of the population) also relies on mainstream concepts about demographic processes and challenges without critically questioning the underlying paradigms (Wilkoszewski 2006).

\section{Conceptualising the geographies of demographic change: Problems and missing links}

In light of these observations, this special issue collects contributions that establish a broader understanding of the "geographies of demographic change" and aims to pay more and closer attention to conceptualising the socio-spatial and sociotemporal configurations. From the authors' point of view, it is important to do so because these configurations are produced by the patterns of demographic developments on multiple scales, but are also reproduced in the debates and policy responses addressing these developments. Thus, this collection of articles intends to pick up the loose ends which have been left unexamined by various sub-disciplines and to elaborate upon the cross-disciplinary interfaces. Moreover, it seems necessary to add new elements to the research agenda, which reveal how demographic 
discourses are constructed at the level of society, the economy and the region, how narratives about demographic change are built, communicated and legitimated, and why discourses are held in specific ways.

\subsection{Unresolved issues and conceptual problems}

Most debates about demographic change in research and practice are based upon a practical approach, using empirical data, statistical indicators, field observations, and case studies to derive policy recommendations. Indeed, the bulk of the scholarly knowledge that has been generated focuses on quantitative problem analysis, pilot projects or "best practice" templates for policymaking. This positivist approach to the "geographies of demographic change" hides the discursive power associated with its interpretation of "change" in terms of "decline", at least from a European perspective, and may therefore disguise alternative concepts which are more context-sensitive and take on a neutral position against analysis and appraisal of these phenomena.

In addition, many theories and approaches rely on dominant paradigms such as "economic growth" and "economic competitiveness", which, however, fail to provide appropriate explanations of the greater challenges of demographic change (see Matuschewski et al. 2017 in this issue). In this respect, a general problem with most economic approaches (exceptions include endogenous growth theories, see Aghion/Howitt 1998) is that demographic change is often considered as an exogenous factor which influences economic growth prospects or quantitative economic development on various scales. However, the inherent complexity of phenomena such as population ageing, population decline or demographic heterogeneity (as measured by [net] migration flows and differences in fertility behaviour over time) makes it difficult to predict their effects on regional growth and competitiveness (Poot 2008). Alternative ideas about the interfaces between economy and demography are still at an early stage; for example, quality of life, well-being or minimum standards for the provision of public goods and services are discussed as points of reference for conceptualising this link. In geographical and regional research, this paradigm partially overlaps with other, more context-specific discourses about conditions of rurality or peripherality (Danson/De Souza 2012), urbanisation (García Docampo 2014; Storper/Manville 2006), centralisation and decentralisation (Bes/ey/ Coate 2003), and the system transformation of economies (such as the post-socialist transformation, see Grabher/Stark 1997; Stark/Bruszt 1998). Hence, theoretical approaches to describe the geographies of demographic change need to refer to both different and to related debates, but implicitly hypothesise that socio-spatial entities and economies are supposed to follow a somewhat pre-determined economic growth path.

Consequently, the assumption of economic growth in terms of increases or stability in income and employment over time remains unchallenged, cutting across most demographic discourses as a normative paradigm and conceptualising demographic change as a problematic context for long-term economic growth prospects. Indeed, this stance fails to capture the complexity of its systemic character. Alter- 
native topics emerging in the recent discussions on the systemic transformations of economies and societies are associated with a sustainability approach (Hansen/ Coenen 2015; Schulz 2014) and endogenous, network-based local development (Amin 1999; Huggins/Thomson 2014). From a normative, public policy perspective, integrating these new research topics is still in its infancy. More generally, this special issue attempts to discuss the dominant normative paradigms underlying these debates critically, taking into account the overlapping topics and challenges.

\subsection{Missing elements and alternative conceptualisations}

Against this background, this editorial argues that the wider field of the social sciences lacks a broad academic discussion that considers the narratives and discourses that are built in practice, policymaking and research to refer to the changes that lie ahead for societies, economies and regions. Thus, the conceptual work resulting from scholarly engagement with the phenomenon of demographic change remains somewhat fragmented. The present special issue thus offers some building blocks which may complement the prevailing understanding of these phenomena because they pay specific attention to the conceptual and narrative perspectives underlying the "geographies of demographic change".

Regarding conceptualisation, the following questions are asked:

- Which conceptual approaches describing demographic change and its effects on societies and economies are used in what fields or disciplines within the social sciences?

- How are these concepts connected with the way that demographic change is represented in contemporary debates?

- How and to what extent is the systemic character of demographic change considered or stressed?

- What might be the potential gains of such theoretical explanations? How can (so far) underrepresented conceptual ideas about demographic change enrich the existing academic, public and political discussion in a European context?

The special issue also discusses discourses and narratives associated with demographic change such as the following issues:

- Which narratives describe the geographies of demographic change?

- Why is demographic change predominantly negatively connoted in the European context, for instance, with "decline", "withdrawal" or "adaptation", instead of more positively connoted terms such as "renewal" or "resilience"?

- What do alternative - and perhaps more optimistic - interpretations of demographic change (for instance, demographic resilience) look like?

- What impact does the one-sidedness of negative connotations associated with demographic change produce in the public and scholarly discourse have? 
The special issue reflects upon the role of agency, claiming that it is necessary to describe and analyse in greater depth the role that individual actors involved at different levels (civil society, private enterprises and industry, the state and its representatives, such as governments or municipalities, etc.) play in the process of socio-spatial change caused by or accompanying demographic processes. Such actors can be important facilitators of endogenous development due to their resource endowments (human capital, knowledge, and skills) or because they can act as gatekeepers between different communities and contextual settings. However, individual agency may also reproduce existing narratives about demographic change, such as the growth paradigm. This might be the case when ignorance on the part of key actors towards complex future changes and adherence to past ways of handling processes of change persist even if and when change becomes visible. From a social psychology perspective, such behaviour can be interpreted as an irrational reaction to crisis (Folkman/Lazarus 1990; Furnham 2005). Notwithstanding this, the contradictions in the actions and behaviour of such agents have not been fully acknowledged as an important element to describe the "geographies of demographic change". Therefore, an agency-centric perspective is important to better understand demographic processes on different levels. From a policy perspective, policymakers should pay particular attention to the different, and often paradoxical, roles of agents who steer, accompany and communicate demographic change processes.

To avoid such fallacies, context and self-reflexivity are crucial lenses through which to observe demographic change from a multi-level, multi-actor and multiscalar perspective as a context-specific phenomenon. This makes it necessary to reflect upon the paradigms underlying existing descriptions and explanations. Such paradigms include the concept of economic growth and the recent post-growth debates (Ferguson 2015; Schulz 2014), the rural-urban divide (Hoggart 1990), and the dominating rationalist, engineering-based planning approaches (Albrechts 2004: 745). Most importantly, criticism of these paradigms should include the extent to which they address the systemic character of demographic change. At the local level, the specific conditions associated with demographic change may overlap with problems caused by rural or peripheral contexts, thereby reinforcing negative prospects for sustainable local development. Consequently, regions and actors embedded in such regions are "locked in" (Hassink 2010), and new approaches to local problem-solving are needed to move ahead in such cases.

Normative power also plays an important role for conceptualising demographic change. In fact, policymaking generally seems to ignore the dynamics of demographic change whilst keeping a focus on growth strategies through job creation and the assignment of new housing or production sites. With some exceptions, most policies addressing demographic change are reactive, rather than proactively working with specific constellations such as a certain population size or structure. For the case of Germany, strategies to counteract or mitigate demographic change at the local level tend to neglect or even overlook the necessity of context- and place-specific governance schemes which could strengthen local resources (including networks and social capital) and enlarge the scope of core actors (such as civil 
society, private companies, ageing residents, etc.). Even though there have been numerous model projects on the national and the European levels on how to cope with demographic change, many municipalities widely neglect the effects of demographic changes and pursue a strategy of "muddling through", rather than actively implementing middle- and long-term multilevel governance strategies of adaptation (see, for instance, Jonda 2012; König 2014).

\section{$4 \quad$ What lies ahead? Towards establishing a conceptual understanding of the "geographies of demographic change"}

The papers in this special issue aim to establish a broader understanding of what we call the "geographies of demographic change". Matuschewski et al. (2017) start this discussion by criticising the growth-oriented regional development theories and policies which are most typically referred to in the social sciences and economics. In their paper, the authors search for alternative conceptual frameworks to describe regional development theories for regions affected by demographic change, frameworks which go beyond the growth paradigm. To this aim, Matuschewski et al. (2017) use Scholz' (2007) idea of "globalisation peripheries" for a better understanding of the demographic-economic vicious circle of many particularly ruralperipheral contexts. "Globalisation peripheries" allude to the interconnectedness of demographic and economic processes, which they consider to be a neglected facet in the conceptual approaches used for describing demographic change. The East German region of Altenburger Land serves as a case in which this overlap of demographic and economic factors does not comply with a growth-based regional development trajectory.

In a similar vein, the prevalent regional planning approaches for rural-peripheral places can be criticised because of the lack of reflection on their conceptual underpinnings. All too often, socio-cultural processes are simply equated with demographic change. For instance, selective outmigration is often called the "demographisation" of local development of rural-peripheral regions. In their paper, Leibert and Golinski (2017) introduce "peripheralisation" as an alternative, and more sophisticated, perspective on regional development, which better contextualises the multi-layered problems and challenges for rural-peripheral, demographically changing regions. According to the authors, peripheralisation is a missing link that helps connect the overlapping discourses on demographic change, rurality and peripherality. Leibert and Golinski (2017) also conclude that peripheralisation is a useful point of departure for planning approaches to overcome deficits and flaws in the

1 See, for example, the demographic strategy of the German Federal Government (https:// www.bundesregierung.de/Webs/Breg/DE/Themen/Demografiestrategie/_node.html), the programme focus "Health, Demographic Change and Wellbeing" within the EU Framework Programme for Research and Innovation HORIZON 2020 (http://ec.europa.eu/programmes/horizon2020/en/h2020-section/health-demographic-change-and-wellbeing,) or the demographic change regions network (http://dcrn.eu/). 
policymaking for such regions. The paper points out that public intervention policies to adapt to peripheralisation on the one hand and private commitment through civic action on the other hand are two distinct instruments suited for policymaking based upon the peripheralisation hypothesis.

Both Matuschewski et al. (2017) and Leibert and Golinski (2017) offer new interpretations of the mainstream growth-based concepts for demographic change, which are still the uncontested and primary targets of many economic policy programmes. In doing so, they challenge the assumption that demographic processes are irreversible. Meyer et al. (2017) introduce another argument to this discussion by approaching demographic change from a discursive perspective that focuses on "stigmatisation". In their paper, the authors show how stigmata and stigmatisation in demographically declining, peripheral regions are produced and reproduced through the discourses and narrations of local adolescents. Meyer et al. (2017) thus provide a conceptualisation of the precarious, crisis-ridden context of rural-peripheral, declining places from a social psychological perspective, which embeds demographic change in a social geographical understanding. Their empirical case study of the Altenburger Land emphasises this argument.

Indeed, examining the discourses on demographic change and its importance can be helpful to disentangle the demographic and social roots of these debates or the positions which actors take. Bartl and Sackmann (2017) provide an interesting case study of media discourses and representations in speech about school closures due to local population decline and ageing, highlighting how local practices are reflected in mainstream media coverage and the representations derived therefrom. A central finding of this contribution is that the social stratifications of the local population, which are significantly and adversely affected by outmigration, ageing, etc., are, indeed, re-produced through the discourses of local policymakers and the media.

In the next paper, Christmann (2017) moves away from discourses of stigmatisation, i.e., a narrative that views demographic change as a problematical context. Instead, social innovation is proposed as a trigger of local-regional development in peripheralised contexts. Agency then becomes central to resolving "negative" discourses and inspires local stakeholders to launch counter-discourses that stress the chances and opportunities associated with demographic challenges, rather than the problems and stigmata. Another important mechanism to produce such "positive narratives" is pro-active local communication and media coverage, which the author stresses based upon an empirical case study from East Germany.

Hence, contextualising local-regional development processes and the impact of demographic change on specific contexts by considering historical path-dependencies, the place-specific social stratification and local institutions is crucial for understanding the complexity of the various configurations. Rural-peripheral Nordic regions offer a context in which demographic change had been embedded in specific mitigating strategies for a long time (Persson 2003). Carson et al. (2016) propose demographic resilience as a conceptual lens for describing and analysing contextspecific inter-related phenomena such as rurality, peripherality, and the association of demographic and societal change. By comparing regions in rural Sweden and 
Australia, the authors give examples of how such peripheral regions could be transformed into "resource peripheries" to enhance local economic development.

\section{References}

Albrechts, Louis 2004: Strategic (spatial) planning reexamined. In: Environment and Planning B 31,5: 743-758 [doi: 10.1068/b3065].

Aghion, Philippe; Howitt, Peter 1998: Endogenous growth theory. Cambridge: The MIT Press.

Amin, Ash 1999: An institutionalist perspective on regional economic development. In: International Journal of Urban and Regional Research 23,2: 365-378 [doi: 10.1111/14682427.00201].

Andersson, Gunnar 2004: Childbearing after Migration: Fertility patterns of foreignborn women in Sweden. In: International Migration Review 38,2: 747-774 [doi: 10.1111/ j.1747-7379.2004.tb00216.x].

ARL (Akademie für Raumforschung und Landesplanung) 2016: Daseinsvorsorge und gleichwertige Lebensverhältnisse neu denken. Perspektiven und Handlungsfelder (Positionspapier aus der ARL 108). Hannover: ARL.

Barbi, Elisabetta; Bongaarts, John; Vaupel, James W. (Eds.) 2008: How long do we live? Demographic models and reflections on tempo effects. Demographic Research Monographs 5. Berlin: Springer.

Barlösius, Eva; Neu, Claudia 2007: "Gleichwertigkeit - Ade?" Die Demographisierung und Peripherisierung entlegener ländlicher Räume. In: PROKLA. Zeitschrift für kritische Sozialwissenschaft 37,1: 77-92.

Bartl, Walter; Sackmann, Reinhold 2016: Governance Indicators and Responsiveness to Population Decline: School Closures in Practice and Discourse in Saxony-Anhalt. In: Comparative Population Studies 41,3-4: 321-358 [doi: 10.12765/CPoS-2016-09en].

Baudisch, Annette 2008: Inevitable aging? Contributions to evolutionary-demographic theory. Demographic Research Monographs 4. Berlin: Springer.

BMVBS (Bundesministerium für Verkehr, Bau und Stadtentwicklung); BBSR (Bundesinstitut für Bau-, Stadt- und Raumforschung) (Eds.) 2009: Ländliche Räume im demografischen Wandel. BBSR-Online-Publikation 34/2009 [urn:nbn:de:0093-ON3409R142, 28/01/2016].

Bengtsson, Tommy; Scott, Kirk 2011: Population aging and the future of the welfare state: the example of Sweden. In: Population and Development Review 37, Supplement s1: 158-170 [doi: 10.1111/j.1728-4457.2011.00382.x].

Besley, Timothy; Coate, Stephen 2003: Centralized versus decentralized provision of local public goods: a political economy approach. In: Journal of Public Economics 87,12: 2611-2637 [doi: 10.1016/S0047-2727(02)00141-X].

Birdsall, Nancy; Kelley, Allen C.; Sinding, Steven (Eds.) 2001: Population matters. Demographic change, economic growth, and poverty in the developing world. Oxford: Oxford University Press.

Bloom, David E.; Canning, David; Sevilla, Jaypee 2003: The demographic dividend. A new perspective on the economic consequences of population change. Santa Monica: RAND. 
Bloom, David E.; Canning, David 2008: Global Demographic Change: Dimensions and Economic Significance. In: Prskawetz, Alexia et al. (Eds.): Population Aging, Human Capital Accumulation, and Productivity Growth. Population and Development Review 34, Supplement. New York: Population Council: 17-51.

Bloom, David E.; Canning, David; Fink, Guenther 2010: Implications of population ageing for economic growth. In: Oxford Review of Economic Policy 24,4: 583-612 [doi: 10.1093/oxrep/grq038].

Bönte, Werner; Falck, Oliver; Heblich, Stephan 2007: Demography and innovative entrepreneurship, CESifo working paper, No. 2115. Munich: Ifo Institute.

Börsch-Supan, Axel 2008: The Impact of Global Aging on Labor, Product and Capital Markets. In: Prskawetz, Alexia et al. (Eds.): Population Aging, Human Capital Accumulation, and Productivity Growth. Population and Development Review 34, Supplement. New York: Population Council: 52-77.

Börsch-Supan, Axel 2013: Myths, scientific evidence and economic policy in an aging world. In: The Journal of the Economies of Aging 1-2: 3-15 [doi: 10.1016/j. jeoa.2013.06.001].

Börsch-Supan, Axel et al. 2015: Savings in times of demographic change: Lessons from the German experience. In: Journal of Economic Surveys 29,4: 807-829 [doi: 10.1111/ joes.12116].

Brown, Ross; Danson, Mike 2003: 'Going grey': demographic change and the changing labour market in Scotland. In: Local Economy 18,4: 291-305 [doi: 10.1080/0269094032000154997].

Cangiano, Alessio 2014: Elder care and migrant labor in Europe: A demographic outlook. In: Population and Development Review 40,1: 131-154 [doi: 10.1111/j.17284457.2014.00653.x].

Carson, Dean B. et al. 2016: Decline, Adaptation or Transformation: New Perspectives on Demographic Change in Resource Peripheries in Australia and Sweden. In: Comparative Population Studies 41,3-4: 379-406 [doi: 10.12765/CPoS-2016-11en].

Christmann, Gabriela B. 2017: Analysing Changes in Discursive Constructions of Rural Areas in the Context of Demographic Change. Towards Counterpoints in the Dominant Discourse on "Dying Villages". In: Comparative Population Studies 41,3-4: 359-378 [doi: 10.12765/CPoS-2017-03en].

Coale, Ansley 1975: The demographic transition. In: United Nations (Ed.): The population debate. Dimensions and perspectives. Volume 1. New York: United Nations: 347355.

Danson, Mike; De Souza, Peter (Eds.) 2012: Regional development in Northern Europe: Peripherality, marginality and border Issues. Abingdon: Routledge.

Ehrhardt, Jens; Kohli, Martin 2011: Individualisation and fertility. In: Historical Social Research 36,2: 35-64.

Ferguson, Peter 2015: The green economy agenda: business as usual or transformational discourse? Environmental Politics 24,1: 17-37.

Ferry, Martin; Vironen, Heidi 2011: Dealing with Demographic Change: Regional Policy Responses. In: Geopolitics, History and International Relations 3,1: 25-58.

Folkman, Susan; Lazarus, Richard S. 1990: Coping and Emotion. In: Stein, Nancy L.; Leventhal, Bennett; Trabasso, Tom (Eds.): Psychological and Biological Approaches to Emotion. New York: Springer: 313-332.

Franz, Peter 2004: Shrinking cities - shrinking economy? The case of East Germany. In: German Journal of Urban Studies (Difu) 44,1. 
Furnham, Adrian 2005: Psychology at work: The individual in the organisation. Hove: Psychology Press.

Gans, Paul; Schmitz-Veltin, Ansgar; Akademie für Raumforschung und Landesplanung - Leibniz-Forum für Raumwissenschaften (Eds.) 2006: Demographische Trends in Deutschland: Folgen für Städte und Regionen (Forschungs- und Sitzungsberichte der ARL 226). Hannover: ARL.

García Docampo, Manue/ 2014: Theories of urban dynamics. In: International Journal of Population Research 2014 [doi: 10.1155/2014/494871].

Grabher, Gernot; Stark, David (Eds.) 1997: Restructuring networks in post-socialism. Legacies, Linkages, and Localities. Oxford: Oxford University Press.

Green, Anne E. 2003: Labour market trends, skill needs and the ageing of the workforce: a challenge for employability? In: Local Economy 18,4: 306-321 [doi: 10.1080/0269094032000153835].

Goldstone, Jack A.; Kaufman, Eric P.; Toft, Monica D. (Eds.) 2012: Political demography: how population changes are reshaping international security and national politics. Oxford: Oxford University Press.

Hansen, Teis; Coenen, Lars 2015: The geography of sustainability transitions: review, synthesis and reflections on an emergent research field. In: Environmental Innovation and Societal Transitions 17: 92-109 [doi: 10.1016/j.eist.2014.11.001].

Harhoff, Dietmar 2008: Innovation, Entrepreneurship und Demographie. In: Perspektiven der Wirtschaftspolitik 9, supplement s1: 46-72 [doi: 10.1111/j.1468-2516.2008.00274.x].

Hassink, Robert 2010: Locked in Decline? On the Role of Regional Lock-in's in Old Industrial areas. In: Boschma, Ron; Martin, Ron (Eds.): Handbook of Evolutionary Economic Geography. Cheltenham: Edward Elgar: 450-468 [doi: 10.4337/9781849806497.00031].

Hassink, Robert 2005: How to unlock regional economies from path dependency? From learning region to learning cluster. In: European Planning Studies 13,4: 521-535.

Hoggart, Keith 1990: Let's do away with rural. In: Journal of Rural Studies 6,3: 245-257 [doi: 10.1016/0743-0167(90)90079-N].

Huggings, Robert; Thomson, Piers 2014: A network-based view of regional growth. In: Journal of Economic Geography 14,3: 511-545 [doi: 10.1093/jeg/lbt012].

Jonda, Bernadette 2012: Zwischen Resignation und Kreativität - Bürgermeister in deutschen Kommunen im Umgang mit aktuellen Herausforderungen des demographischen Wandels. In: Maretzke, Steffen (Ed.): Schrumpfend, alternd, bunter? Antworten auf den demographischen Wandel (=DGD-Online-Publikation 01/2012.). Bonn: DGD: 94-106.

Kelley, Allen C.; Schmidt, Robert M. 2005: Evolution of recent economic-demographic modeling: a synthesis. In: Journal of Population Economics 18,2: 275-300 [doi: 10.1007/s00148-005-0222-9].

Kirk, Dudley 1996: Demographic transition theory. In: Population studies - A journal of demography 50,3: 361-387 [doi: 10.1080/0032472031000149536].

Klüsener, Sebastian; Goldstein, Joshua R. 2016: A long-standing demographic EastWest divide in Germany. In: Population, Space and Place 22,1: 5-22 [doi: 10.1002/ psp.1870].

König, Armin 2014: Demographie kompakt. Erfahrungen und Folgerungen aus dem Impulsprojekt Illingen 2030. Illingen: Eigenverlag. 
Kohlbacher, Florian; Herstatt, Cornelius; Levsen, Nils 2014: Golden opportunities for silver innovation: how demographic changes give rise to entrepreneurial opportunities to meet the needs of older people. In: Technovation 39-40,5: $73-82$ [doi: 10.1016/j. technovation.2014.05.002].

Kohlbacher, Florian; Herstatt, Cornelius (Eds.) 2008: The silver market phenomenon. Business opportunities in an Era of demographic change. Heidelberg: Springer.

Kröhnert, Steffen et al. 2011: Die Zukunft der Dörfer. Zwischen Stabilität und demographischem Niedergang. Berlin: Berlin-Institut für Bevölkerung und Entwicklung.

Kuebler, Anette et al. 2009: Enterprises face the ageing demographic: some options to overcome demographic challenges in a multinational company. In: International Journal of Human Resources Development and Management 9,2-3: 275-293 [doi: 10.1504/ [JHRDM.2009.023456]

Kuhn, Michael; Prskawetz, Alexia; Sunde, Uwe 2014: Health, education, and retirement over the prolonged life cycle: a selective survey of recent research. In: Vienna Yearbook of Population Research 12: 1-22 [doi: 10.1553/populationyearbook2014s001].

Kunisch, Sven; Boehm, Stephen A.; Boppel, Michael 2011: An integrated framework for investigating the challenges and opportunities of demographic change. In: Kunisch, Sven; Boehm, Stephen A.; Boppel, Michael (Eds.): From grey to silver. Heidelberg: Springer: 3-21.

Kurek, Slawomir 2011: Double transitions? Regional patterns of population ageing in Poland. In: Geografiska Annaler Series B 93,2: 163-184 [doi: 10.1111/j.14680467.2011.00367.x].

Leibert, Tim; Golinski, Sophie 2017: Peripheralisation: The Missing Link in Dealing with Demographic Change? In: Comparative Population Studies 41,3-4: 255-284 [doi: 10.12765/CPoS-2017-02en].

Leick, Birgit 2013: Demographischer Wandel als Handlungsfeld regional orientierter Unternehmen? Eine Bestandsaufnahme für Oberfranken. In: Mitteilungen der Fränkischen Geographischen Gesellschaft 59: 101-110.

Lesthaeghe, Ron 1995: The second demographic transition in Western countries: an interpretation. In: Jensen, An-Magritt; Oppenheim Mason, Karen (Eds.): Gender and family change in industrialized countries. Oxford: Clarendon: 17-62.

Lührmann, Melanie 2005: Population ageing and the demand for goods and services, MEA Working Paper No. 95-2005. Mannheim: MEA.

Malmberg, Bo 2012: Fertility cycles, age structure and housing demand. In: Scottish Journal of Political Economy 59,5: 467-482 [doi: 10.1111/j.1467-9485.2012.00590.x].

Maretzke, Steffen 2014: Vom demografischen Wandel besonders betroffene Regionen. Ein wichtiges Thema im Kontext der Demografiestrategie. In: BBSR-Online-Publikation 11/2014. Bonn: Bundesinstitut für Bau-, Stadt- und Raumforschung (BBSR).

Martinez-Fernandez, Cristina et al. 2012: Demographic change and local development: shrinkage, regeneration and social dynamics. Paris: OECD.

Matuschewski, Anke; Leick, Birgit 2012. Wirtschaftsentwicklung in demographischen Schrumpfungsregionen. Unternehmerische Herausforderungen und Strategien am Beispiel von Oberfranken. In: Raumforschung und Raumordnung 70,6: 515-530 [doi: 10.1007/s13147-012-0200-0]

Matuschewski, Anke; Leick, Birgit; Demuth, Marcel 2017: Growth-based Theories for Declining Regions? A Note on Conceptualisations of Demographic Change for Regional Economic Development. In: Comparative Population Studies 41,3-4: 225-254 [doi: 10.12765/CPoS-2017-04en]. 
Meier, Volker; Werding, Martin 2010: Ageing and the welfare state: securing sustainability. In: Oxford Review of Economic Policy 26,4: 655-673 [doi: 10.1093/oxrep/grg031].

Meyer, Frank; Miggelbrink, Judith; Schwarzenberg, Tom 2016: Reflecting on the Margins: Socio-spatial Stigmatisation among Adolescents in a Peripheralised Region. In: Comparative Population Studies 41,3-4: 285-320 [doi: 10.12765/CPoS-2016-10en].

Misoulis, Nicholas 2008: Demographic effects on economic growth and consequences for the provision of pensions. In: Economic Affairs 28,1: 29-34 [doi: 10.1111/j.14680270.2008.00797.x].

Neu, Claudia (Ed.) 2009: Daseinsvorsorge. Eine gesellschaftlich-wissenschaftliche Annäherung. Wiesbaden: VS Verlag.

Nuissl, Henning; Rink, Dieter 2005: The 'production' of urban sprawl in Eastern Germany as a phenomenon of post-socialist transformation. In: Cities 22,2: 123-134 [doi: 10.1016/j.cities.2005.01.002].

Oliveira Martins, Joaquium et al. 2005: The impact of ageing on demand, factor markets and growth. OECD Economics Department Working Papers No. 420 [doi: 10.1787/545827207132].

Persson, Lars Olof 2003: Anpassungsstrategien für Regionen mit starkem Bevölkerungsrückgang - Gibt es solche Strategien für Schweden? In: Informationen zur Raumentwicklung 12/2003: 719-723.

Pompe, Hans-Georg 2012: Boom-Branchen 50 Plus. Wie Unternehmen den Best-AgerMarkt für sich nutzen können. Wiesbaden: Gabler Verlag.

Poot, Jacques 2008: Demographic change and regional competitiveness: the effects of immigration and ageing. In: International Journal of Foresight and Innovation Policy 4,1-2: 129-145 [doi: 10.1504/IJFIP.2008.016910].

Reidl, Andreas 2007: Seniorenmarketing. Mit älteren Zielgruppen neue Märkte erschließen. Landsberg am Lech: MI Verlag.

Sackmann, Reinhold; Jonda, Bernadette; Reinhold, Maria (Eds.) 2008: Demographie als Herausforderung für den öffentlichen Sektor. Wiesbaden: VS Verlag für Sozialwissenschaften.

Sánchez Gassen, Nora E. 2013: Germany's future electors: the influence of demographic changes and legal reforms on the development of the electorate. Wiesbaden: VS Verlag für Sozialwissenschaften.

Scholz, Fred 2007: Entwicklungsländer. Braunschweig: Westermann.

Schulz, Christian 2014: The green economy and post-growth regimes: opportunities and challenges for economic geography. In: Geografiska Annaler Series B 96,3: 277 291 [doi: 10.1111/geob.12051].

Sobotka, Tomas; Skirbekk, Vegard; Philipov, Dimiter 2011: Economic recession and fertility in the developed world. In: Population and Development Review 37,2: 267-306 [doi: 10.1111/j.1728-4457.2011.00411.x].

Stark, David; Bruszt, Laszlo (Eds.) 1998: Postsocialist pathways: transforming politics and property in East Central Europe. Cambridge: Cambridge University Press.

Steinführer, Annett; Haase, Annegret 2007: Demographic change as a future challenge for cities in East Central Europe. In: Geografiska Annaler Series B 89,2: 183-195 [doi: 10.1111/j.1468-0467.2007.00247.x].

Steinführer, Annett; Küpper, Patrick; Tautz, Alexandra 2014: Anpassen und Bewältigen: Strategien zur Sicherung von Lebensqualität in einer schrumpfenden Alterungsregion. In: Comparative Population Studies 39,2: 319-344 [doi: 10.12765/CPoS-2014-07de] 
Storper, Michael; Manville, Michael 2006: Behaviour, preferences and cities: urban theory and urban resurgence. In: Urban Studies 43,8: 1247-1274 [doi: 10.1080/00420980600775642].

Streb, Christoph K.; Voelpel, Sven C.; Leibold, Marius 2008: Managing the aging workforce: Status quo and implications for the advancement of theory and practice. In: European Management Journal 26,1: 1-10 [doi: 10.1016/j.emj.2007.08.004].

Suprinovic, Olga; Kay, Rosemarie 2009: Demografischer Wandel und die absatzpolitischen Anpassungsmaßnahmen kleiner und mittlerer Unternehmen. In: Zeitschrift für Betriebswirtschaft 6, special issue: 113-133.

Swiaczny, Frank 2010: Implications of demographic change for civil society in Germany. In: Journal of Population Research 27,3: 193-211 [doi: 10.1007/s12546-010-9041-2].

Thompson, Warren 1929: Population. In: American Journal of Sociology 34,6: 959-975.

Thun, Joern-Henrik; Größler, Andreas; Miczka, Switbert 2007: The impact of the demographic transition on manufacturing: effects of an ageing workforce in German industrial firms. In: Journal of Manufacturing Technology Management 18,8: 985-999 [doi: 10.1108/17410380710828299].

Tulik, Carol T. 2014: From the editors: Aging populations and management. In: Academy of Management Journal 57,4: 929-935 [doi: 10.5465/amj.2014.4004].

Van de Kaa, Dirk J. 1994: The second demographic transition revisited: Theories and expectations. In: Beets, Gijs et al. (Eds.): Population and family in the Low Countries 1993: Late fertility and other current issues. Lisse: Swets \& Zeitlinger: 81-126.

Van de Kaa, Dirk J. 1996: Anchored Narratives: The Story and Findings of Half a Century of Research into the Determinants of Fertility. In: Population Studies 50,3: 389-432 [Stable URL: http://www.jstor.org/stable/2174640].

Vande Kaa, DirkJ. 2001: Postmodernfertility preferences: From changing value orientation to new behavior. In: Population and Development Review 27, supplement: 290-331 [Stable URL: http://www.jstor.org/stable/3115262].

Verworn, Birgit; Schwarz, Doreen; Herstatt, Cornelius 2009: Changing workforce demographics: strategies derived from the resource-based view of HRM. In: International Journal of Human Resource Development and Management 9,2-3: 149-161 [10.1504/ IJHRDM.2009.02345].

Wilkoszewski, Harald 2006: Politikberatung im Bereich Demographischer Wandel. In: Falk, Svenja et al. (Eds.): Handbuch Politikberatung. Wiesbaden: VS Verlag für Sozialwissenschaften: 496-508.

Associate Professor Dr. Birgit Leick ( $₫)$. Østfold University College, Faculty of Business, Languages, and Social Sciences. Norway. E-mail: birgit.leick@hiof.no

URL: http://www.hiof.no/om-hogskolen/enheter/avdeling-for-okonomi_-sprak-ogsamfunnsfag/om-avdelingen/ansatte

Prof. Dr. Birgit Glorius. University of Technology Chemnitz, Chair of Human Geography and Eastern European Studies. Chemnitz. Germany.

E-mail: birgit.glorius@phil.tu-chemnitz.de

URL: https://www.tu-chemnitz.de/phil/europastudien/geographie/Mitarbeiter/inhab.php 


\section{Comparative Population Studies}

wWW.comparativepopulationstudies.de

ISSN: 1869-8980 (Print) - 1869-8999 (Internet)

\section{Published by}

Prof. Dr. Norbert F. Schneider

Federal Institute for Population Research D-65180 Wiesbaden / Germany

\section{(cc) BY-SA}

2017

\section{Managing Editor}

Frank Swiaczny

\section{Assistant Managing Editor}

Katrin Schiefer

\section{Copy Editor}

(Selected Articles in German)

Dr. Evelyn Grünheid

\section{Layout}

Beatriz Feiler-Fuchs

E-mail: cpos@bib.bund.de

\section{Scientific Advisory Board}

Paul Gans (Mannheim)

Karsten Hank (Cologne)

Johannes Huinink (Bremen)

Michaela Kreyenfeld (Rostock)

Marc Luy (Vienna)

Notburga Ott (Bochum)

Peter Preisendörfer (Mainz)

Nikola Sander (Groningen)

Zsolt Spéder (Budapest)

\section{Board of Reviewers}

Martin Abraham (Erlangen)

Laura Bernardi (Lausanne)

Hansjörg Bucher (Bonn)

Claudia Diehl (Konstanz)

Andreas Diekmann (Zurich)

Gabriele Doblhammer-Reiter (Rostock)

Jürgen Dorbritz (Wiesbaden)

Anette Eva Fasang (Berlin)

E.-Jürgen Flöthmann (Bielefeld)

Alexia Fürnkranz-Prskawetz (Vienna)

Beat Fux (Salzburg)

Joshua Goldstein (Berkeley)

Sonja Haug (Regensburg)

Hill Kulu (Liverpool)

Aart C. Liefbroer (The Hague)

Kurt Lüscher (Konstanz)

Emma Lundholm (Umeå)

Nadja Milewski (Rostock)

Dimiter Philipov (Vienna)

Roland Rau (Rostock)

Tomáš Sobotka (Vienna)

Jeroen Spijker (Barcelona)

Olivier Thévenon (Paris)

Helga de Valk (Brussels)

Heike Trappe (Rostock)

Michael Wagner (Cologne) 